\title{
Elements for the Personal and Professional Development of Teachers
}

\author{
Aline Rocha Mendes'1, Karina Pacheco Dohms' ${ }^{1}$ Carla da Conceição Lettnin1, \\ Juan José Mouriño Mosquera' ${ }^{2}$, Claus Dieter Stobäus ${ }^{3}$ \\ ${ }^{1}$ Postgraduate Programs in Education, Pontifical Chatolic University of Rio Grande do Sul, Porto Alegre, Brazil \\ ${ }^{2}$ Postgraduate Programs in Education, Pro-Rectory of Postgraduate and Research, Pontifical Catholic University \\ of Rio Grande do Sul, Porto Alegre, Brazil \\ ${ }^{3}$ Postgraduate Program in Education and in Biomedical Gerontology, Pontifical Chatolic University of Rio \\ Grande do Sul, Porto Alegre, Brazil \\ Email: stobaus@pucrs.br
}

Received 8 June 2016; accepted 9 July 2016; published 12 July 2016

Copyright (C) 2016 by authors and Scientific Research Publishing Inc.

This work is licensed under the Creative Commons Attribution International License (CC BY).

http://creativecommons.org/licenses/by/4.0/

(c) (†) Open Access

\section{Abstract}

Using a qualitative approach, this article aims to list the aspects that influence and generate conditions for the well-being as well as reflect on how this welfare could contribute to the personal and professional development of teachers, taking into account the cycles of the teaching profession, health and quality of life. The theoretical framework is based on Maslow, Huberman, Jesus, Marchesi and Stobäus \& Mosquera studies. Knowing that teachers can experience both conditions, during their working lives, malaise as welfare, and that it will depend on how they deal with different situations in which they are teaching, we understand that the teachers themselves can also develop their resources in order to improve their quality of personal and professional life, through elements of Positive and Heath Psychology, investing in their resilience, in coping strategies and developing aspects of his affectivity and healthier interpersonal relationships. Interventions are added elements held in educational realities.

\section{Keywords}

Teacher Welfare, Teacher Development, Cycles of the Teaching Profession, Positive Psychology

\section{Introduction}

We are facing a reality in which the teaching profession is no longer valued. In recent decades many changes occurred in the social, economic and political, along with greater democratization of knowledge, made the 
teacher, before respected and considered the only source of knowledge, lost its social recognition, status. These changes, coupled with the lack of preparation in teacher training and the loss of values in society, contributed to the current teacher is exposed to adverse environments, given the various adversities and obstacles to be faced, which consequently affect their pedagogical work, generating the malaise in teaching, current cause of numerous health clearances in the educational sector.

Although the teacher malaise has been investigated for nearly more than 40 years ago, concern about teacher health became relevant, scientifically, in the last fifteen years, says Zacharias, Mendes, Lettnin, Dohms, Mosquera, \& Stobäus (2011).

However, it is perceived in our country that no data or sufficient referrals to improve working conditions for teachers are submitted, in a forward perspective of solutions, while he/her is leading to some sick.

The health of the teacher, so far, has never been taken very seriously by public policy proposals at the level of Education Systems and in some schools, which can be considered as a failure (or inaction) by the responsible for creating and implementation of pedagogical proposals. However, we have also teachers who are successful, resistant and resilient educators, despite the complex situations experienced in the area of Education, they can develop well-being in their profession.

In this universe of variables that generate insecurities, uncertainties, wear and consequent illness, there appears the Positive and the Health Psychology, in order to investigate the positive side of being human

Jesus \& Rezende (2009) clarify that, according to Compton, the objective of Positive Psychology is assist in developing skills and able competencies to circumvent the unfavorable situations towards the personal and professional development and satisfaction, dedicating their studies to positive emotions, well-being, happiness, joy, optimism, hope, love, forgiveness, among others.

Seligman \& Csikszentmihalyi (2000: p. 5) state that "the goal of Positive Psychology is to begin to catalyze a change in the focus of Psychology only concern with the repair of the worst things in life to also build the positive qualities". Thus, studies of Positive Psychology aim to browse and search the positive individual traits in order to investigate the reasons why life is worth living, emphasizing the quality of life and well-being.

Accordingly Maslow (1991), all people of our society (except a few pathological exceptions) have need or desire for a generally high valuation of themselves, with a firm and stable base; needs of self-respect or self-esteem, and esteem of others.

Mosquera \& Stobäus (2006), apud Timm, Mosquera, \& Stobäus, (2008) remember that the nature of selfimage, self-esteem is based through the knowledge that the subject makes of himself in the development of their potential, in the perception of feelings, attitudes and ideas concerning the personal dynamics. The authors also emphasize that self-esteem is part of the identity process, leading the subject to this self knowledge, the appreciation of the possibilities, the confidence to overcome and to attempt to "self-update" himself and self-realization.

We stress the importance of also personal development of these professionals, have desires and need support with its daily demands as teachers. Enable these professionals, throughout his career, and have space to worry about their integral training.

Mosquera, Stobäus, Jesus, \& Hermínio (2006: p. 6) point out that "the role of a healthier teacher who has better interpersonal relationships, should undoubtedly lead their students (and himself) to self-realization, assuming get to be someone and do something that is relevant for us ourselves and others".

\section{Cycles of the Teaching Profession}

Some authors, in order to better understand the teaching professional, conducted researches on the development of the teacher's career. We will quote here the studies of Huberman (1995) and Marchesi (2008).

In the studies of Huberman (1995), the author distinguished professional stages that are experienced by teachers: career entry; stabilization; diversification; put himself in question; serenity; conservatism; divestment. Recalling that such phases do not occur necessarily in a linear fashion and that not all of them are experienced by the teacher, because the development of the teaching profession is a subjective process. That is, some educators can experience the stabilization phase earlier than others, or may never stabilize, or even often experience the exploration phase, or may not go through the stage of diversification or put in question.

In the identified stages of Huberman (1995), the first one is entry into the career, that corresponds to the first years of teaching. It is an exploration stage it can be easy (if the start is characterized by an initial enthusiasm, the satisfaction with the educational praxis) or problematic (if an initial confrontation characterized by the clash 
with the reality of the classroom and the difficulties that present in the pedagogical action, and/or discovery).

Explains that these two stages, in most cases, are experienced in parallel, however, for some teachers of the stages may be the winning.

The stabilization phase is the final commitment to the profession, the identification with being a teacher, the claim to colleagues with more experience, and the waiver of other professional opportunities. It is a period marked by feelings of confidence, competence and comfort, where the teacher feels more comfortable to face adversity and not feel personally responsible for everything that happens with your class.

Diversification is a phase characterized by experimentation and innovation, because after stabilized, the teacher is more secure, motivated and dynamic, seeking new stimuli and ideas and feeling able to modify and diversify their teaching practice avoiding falling in routine. The setting in question concerns the teacher questions facing the monotony, the routine of the classroom, or even against the disenchantment with the profession. The teacher analyzes his/her "entire life", scoring whether to continue or not the same route. This phase corresponds to mid-career, and may arise after the diversification or stabilization, as some teachers can not go through the diversification phase.

The phase of serenity comes mostly after the phase of questioning, characterized by an acceptance of the real Self and not the ideal Self. Thus, the teacher is less vulnerable to the assessment from director, colleagues or students. At this stage, the ambition and investment decrease, while the serenity and confidence increase, because the teaching is accepted as he/she is, not as others want. There is also an emotional distance with respect to students, most likely, due to the chronological distance and generations between teachers and students.

Conservatism is marked by mourning and teacher complaints regarding students, teaching, educational policy, among others. This phase may appear in both the younger teachers as in older, featuring a resistance to innovation and a nostalgia for the past. They can get to this stage after the serenity or to put in longer matter.

The divestment phase corresponds to retreat and career internalization, because the teacher is released from the investment in work to devote more time to himself and to a life of greater reflection. This phase can manifest itself after a serenity phase or conservatism, or even mid-career, if the teacher became disillusioned with the results of their work or their ambitions are not met.

Another author who identified the cycles of the teaching profession was Marchesi (2008), based on studies carried out in Spain and in a survey conducted in Brazil with 3500 teachers from various regions of the country, coordinated by Maria Teresa Perez Soares, in 2007, also systematized some stages of teacher at a proposal that, somehow, take into consideration the proposed cycles per Huberman (1995).

Marchesi (2008) discriminated five stages of teacher professional life: the initial training; the first years; knowledge of the profession; maturity and the final years of the profession. According to him, the way each teacher responds and resolves conflicts will mark their self-esteem, job satisfaction and how you will enter the next step.

The first stage, categorized from the data obtained in Spain, is the initial education, with regard to the future of the undergraduate teacher, before their professional practice. The data show that the Pedagogy students point vocation to be the teaching profession as graduates feel torn between the scientific interest of their area of training and teaching career, getting the evidence that some individuals have faced conflicts even before enter the career.

The second stage, the first years, as the following steps, were categorized from survey data held in Brazil. This second stage is characterized entry into teaching as a professional. This stage covers the first five years of teaching career, may be considered difficult and traumatic for the lack of experience and difficulties encountered. The survey data also show that job satisfaction increases over the years.

The knowledge of the teaching profession can be regarded as the main stage, which takes approximately five to fifteen years of teaching. At this stage the teacher recognizes his work since an active role and as a protagonist. "It is, therefore, a step of knowledge 'from the inside' of the teaching profession, the discovery of its positive and negative aspects, to take responsibility", says Marchesi (2008: p. 49).

The maturity stage usually starts after fifteen years of teaching experience, in which the teacher has already experienced the difficulties, frustrations, fatigue, possibilities, satisfaction and professional success. A rocking and reflection step in which the teacher perceives his/her motivation to move forward or not worth involvement beyond what is required.

The last step, the final years of the profession, after thirty years of teaching, usually are characterized by detachment and less involvement with the profession. However, research carried out in Brazil shows that teachers with more time in the profession do not have negative attitudes and show greater preference for teamwork. 
Marchesi (2008) points out that, in many cases, the educational changes can trigger the critical steps and guide its outcome, not being the age the main factor of change or crisis periods in which they live some teachers.

We highlight that the teacher can experience different stages during his professional career. May experience much discomfort (the educator shall manifest physical and/or psychological negative symptoms as a result of adverse situations that arise in the profession), and well-being (the teacher can motivate himself and conduct himself professionally, by overcoming difficulties and optimization of the profession), depending on how he/she sees the situations that are presented in an educational context.

In this sense, aiming at a personal and professional construction, in a positive and healthy perspective, we believe that the teacher can look for resources to invest in improving his/her quality of life as well as of their profession.

\section{Seeking Personal and Professional Wellness}

Pais-Ribeiro (2009) explains that the well-being is an integral part of health, and health is the variable that best explains the Quality of Life-QOL. The welfare and health, then, are associated with satisfaction in teaching, as professional success is linked to the achievement of personal goals that contribute to the overall QOL of the subject.

Jesus and Rezende (2009: p. 17) claim that welfare is "the result of the positive general direction of the subject to life events", and is linked to another wider concept, that is subjective well-being.

The subjective well-being (SWB) has its roots in studies of the Positive Psychology. Is defined as the affective and cognitive assessment people make of their lives, that is, people know SWB when they experience positive feelings are satisfied with the their lives are involved and committed to activities they deem interesting and when most of their experience is pleasant, according to Diener (2000).

Jesus (2007: pp. 26-27) considers that the teacher well-being can be interpreted by the:

Motivation and achievement of the teacher, because the set of skills (resilience) and strategies (coping) that he/she develops to achieve to meet the demands and professional difficulties, overcoming them and optimizing its own operation.

In this sense, the subject must be proactive against his/her development, it is the educator himself who can invest in the search for personal and professional well-being, marked by some elements and strategies that enable self care.

For Grotberg (2003), resilience can be defined as a person's ability to cross, overlap, face adversity, transforming himself and becoming stronger. It is recognized as a subsidy for the promotion of mental and emotional health, contributing thus to the creation of quality of life.

But the concept of coping, according to Pais-Ribeiro \& Santos (2001), is process-oriented. Refers, i.e., to what people think or do in specific situations and not what people normally do, not being a stable personality trait that can be applied in situations of life in general, but rather a process that involves changes in dynamics and function evaluations and continuous reassessment of the relationship between the individual and the environment.

Thus, resilience can be understood as the capacity of overcoming adversity in a positive way, while coping strategies are the actions used to be able to overcome these adversities. Thus, coping strategies may contribute to the development of resilience in the subject, that is, these two mechanisms may be related for coping with difficulties in people's lives.

Lettnin, Zacharias, Mendes, Dohms, Mosquera, \& Stobäus (2011) understand that resilience has been considered as a singular process of construction of the human throughout life and that can be stimulated by the social and cultural environment in which the subject is inserted, i.e, resilience can and should be encouraged and developed in the educational environment.

There is urgent need to implement and promote during the formation of students and teachers, such as structures, processes and attitudes that help them to be more resilient. So, people will be able to actively contribute to society, according Tavares (2001).

In this sense, resilience is presented as an essential element for the construction and development of the welfare of the teacher, since it promotes their mental and emotional health. Thus, teachers will be able to overcome the difficult times that may arise during their educational practice. As Sousa (2006) say, the situations in the educational process are not repeated and are unpredictable, and it is very important an education for resilience, 
to develop and consolidate this intrinsic capacity in each teacher so that it can overcome many difficulties.

Investing in resilience, school teachers will be promoting academic and social success of students, resulting in a consequent promotion of personal and professional welfare educator, improving their quality of life

Lettnin, Zacharias, Mendes, Dohms, Mosquera, \& Stobäus (2011) point out that another important aspect linked to teacher welfare is affectivity. The authors feel that it is extremely important in education as the relationships between school subjects are based on the encounter of different emotions and affections of human beings at different stages of development of life. They add that understand that the teachers who know how to work with your affection as well as their students experience a greater level of satisfaction than those who deny or have difficulty dealing with their own feelings. It is also pointed by Dohms, Stobäus, \& Mosquera (2012) as the development of more real levels in them self-image, self-esteem and self-actualization.

In surveys of Sastre \& Moreno apud Arantes (2003), they found that at school the emotional is something private and personal, so should not be considered in this context, being rational or logical thought the focus of your attention.

In our view, the teacher who denies affectivity, viewing it as unprofessional, only increases tensions and conflicts in the classroom, transforming it into a hostile and unwelcoming space. To that teachers can understand your emotional state, must learn to evaluate and work with their own emotions and the emotions of their students and colleagues.

Mosquera \& Stobäus (2006: p. 130) says that:

The affectivity, expressed by feelings, reflects the relationships of people, and is essential for vital activity in the surrounding world. By changes of feelings and behavioral expression, we can analyze the change in attitude of the human being in face of changing or static circumstances of his/her life, in certain contexts of time or space.

Also point out that the teacher needs to be educated to affectivity, since we deal with diversity in our everyday school life and we need to respect and openness to understanding the other, and sense of incompleteness of the human condition, thus improving relationships within and interpersonal is to invest in personal and social health, say Mosquera \& Stobäus (2008).

We can also say (Dohms, Lettnin, Mendes, Mosquera, \& Stobäus, 2014) that they are Personal, Social and Institutional Aspects involved in these affectivity considerations.

Emotions are classified according to the context in which they are studied. As explained Casassus (2009: p. 88):

The biology, biochemistry and neurology realize, more precisely, the basic emotional states and the way of "face" in the sense of "embodiment", the emotional states of the body. Psychology, in turn, took charge of the emotional experience, the influence of emotions in the personal history and the formation of personality, among other major areas. Sociology was concerned on the one hand, with the aspects of emotions that have to do with relationships, both among people as these with the environment; on the other hand, with aspects of socialization and culture.

In order to explain more about the intrinsic emotional issues to contemporary educator, initially, we must understand these concepts, because they are coming from different areas of knowledge, as they hold the complexity of the skills necessary for emotional intelligence.

We are emotional beings, it is not possible to separate reason from emotion, then we cannot when we talk about education. Even though often seek decide based only on reason, in turn, it cannot be decontextualized/ disembedded of what we feel or life experiences.

When we become aware of the feelings and feel them, we become more competent in making decisions, both personal, as professional character. If we do not have this ability, tend, according Casassus (2009), to pretend the feelings, since they do not have exact definition to be recognized. Moving away from the feelings and sensations than their cause in our conscious and unconscious, the person in general, and more so for the educator, whose reactions are accompanied by their students, creates an apathy towards the world around him and the influences.

In Casassus (2009: p. 206) finds the following statement:

[...] the teaching practice is a practice both cognitive and emotional. Like humans, the teachers are always under the influence of emotions. When they give lessons, they both feel a mixture of emotions, often contradictory. For example, are enthusiastic, bored, sad, distressed and all at the same time.

This is just one of the many skills related to the teaching profession. Know how to control their feelings is not easy for any person, have the competence to deal with you and the other requires a rational and emotionally able 
to understand and make sense of their own experience. A person who becomes insensitive or detached from their feelings and dreams can become a sick person and lose pleasure in everyday school life.

Mosquera (1978) well pointed to another issue related to removal that can also cause displeasure, and is related to the training and practice of the teacher. In this regard, emphasizes the need for adaptation between the initial teacher training and the reality in which develops his/her pedagogical action, because it will have a greater chance of remaining in career and age in good health if he/she know dealing with grievances and dream of an ideal can be conquered.

Some practical strategies were presented by Mosquera (1978). Teachers can take advantage to invest in their personal and professional well-being throughout his/her life, such as: development of self-consciousness; seek new opportunities for education or continuing education; evaluate the grievances; reassess the workload; devote time to rest and leisure and hobbies have disconnected the creatively education; chat with friends and family; stimulate discussion in groups with other teachers; seek a physical activity that is enjoyable; prevent wearing frustrations in students; seek professional help when all aid already available is not sufficient; in extreme cases opt for a strategic retreat. Such strategies are described in the teacher's responsibility and are not as difficult to put into practice.

Marchesi (2008) also presents some strategies that meet the Mosquera ideas, regarding the personal care and emotional and professional well-being: to be competent in the educational activity; keep colleagues and friends to share and innovate; a sufficient distance and make the compromises with passion.

Regarding this issue, we highlight the study by Mendes, Dohms, Zacharias, Lettnin, Mosquera, \& Stobäus (2011), It qualitatively analyze the studies published in recent years in Brazilian Bank of Theses of Higher Education, by Personnel Training Coordination (named CAPES). The data from Working Groups of the National Association of Graduate Studies and Research in Education (named ANPEd), pointing out some categories related to teaching well-being, namely

1. Social Contribution/Training: it would be the responsibility of the teacher has on the student's education;

2. Professional Achievement/Pleasure: the teacher find yourself satisfied and fulfilled with your choice and professional practice;

3. Recognition/Valuation: would the recognition of teachers' work by the academic and general community;

4. Intra and Interpersonal Relations/Affectivity: would the self and the good relations between people of the educational environment (students, parents, families, managers, employees, others);

5. Qualification: incentive and motivation towards continuing education and the search for update;

6. Working Environment: respect the ideal structure of physical and material resources; Space balanced, positive work;

7. Professional Competence: as the teachers' ability to deal with situations in the school environment, a variety of strategies, knowledge of the subject/content specific;

8. Personality: Teaching Creativity.

9. Status: recovery and social status of the teaching profession;

10. Self: knowledge of himself;

11. Management/Public Policy: is the educational reforms aimed at improving involved in the educational system.

According to these authors, such categories, respecting the complexity of the issue and based on the literature, suggest at least two paths toward the teacher well-being. The first is at the individual level, the increment of some aspects related to these categories appear to be determining factors for this more positive state of self and therefore possibility of personal and professional investment. The second is at the collective level, where some categories related to management agencies and the community in general, act to support, as needed to promote the welfare of teachers.

In his work, Jesus, Sampaio, Stobäus, \& Mosquera (2008) and Jesus et al. (2011) observed that a follow-up interventions allows longitudinally. They note that the workshops of Teachers Support Welfare, to investigate its repercussions, providing conditions for teachers to reflect on their practices and attitudes, both personal and professional life, were conducted to help overcome situations of uneasiness towards the well-being, a continuing and ongoing development process.

There were 19 workshops, covering the physical, social, cognitive, emotional and spiritual dimensions in group work in class and exits the field, in a quantitative and qualitative study, which involved fifteen teachers of elementary and high school in the city of Ibema-PR, between April and December 2006, along with reassess- 
ment after two years. Instruments were used to assess self-image and self-esteem, evaluation of evil/teacher welfare, worked with Descriptive and Inferential Statistics, complemented with interviews of teachers, with additional qualitative data obtained from investigator Field Diary, which were worked with content analysis of Bardin (2006).

The qualitative analysis highlight seven categories and results can envision a considerable reduction in professional stress variables and professional exhaustion, an increase in levels of self-image and self-esteem, improvement in coping strategies used.

After two years still exhibit improvements in order to wellness. From the results of this research, we stresses that this program can help the coping and overcoming discomfort, leading to teacher welfare personally and professionally.

\section{Affectivity in Psychopedagogic Workshops}

Mendes (2011), in his work, emphasizes that Psychopedagogical Workshop Awareness, held five school teachers that held its Master's thesis, starting with text on affectivity (Mosquera \& Stobäus, 2006), allowing a dialogue, review concepts about feelings and emotions and how they affect brain functioning. The teachers emphasized that in their practices, already realize this, and see that the conflicts that occur in the classroom are closely linked to affectivity. They realize that students have relationship difficulties with their peers and sometimes with educators because they can not cope well with themselves and their own emotions, think they should teach this too, and content. Two teachers work with early years and believe that the younger students, the stronger must be the influence of the feelings of these students, and bonding that need in order to win them and also in their relationship with their families.

Also report that there are colleagues who have difficulty dealing with their emotional side, so have more serious problems with the students. They reported that, in your community, there is some belief in a false genetic determinism “father/brother/mother/aunt...was like at that age, so do not have to do", when talking with families to try to mediate cases students with relationship problems. They think that the social aspect has a much greater weight, although they believe in the possible changes, if they are desired and feel and mobilizing these boosters.

It is pointed out and discussed on the following excerpt from the article: "not the school is responsible for all the evils afflicting society, or it is the lifeline, we can get rid of them all” (Mosquera \& Stobäus, 2006: p. 130).

All agreed and said that sometimes, if demotivate-facing social problems that students bring and can not solve. They point out that many lack health facilities and social assistance, which should act together with the school so that they had to offer better assistance to students and their families.

Later, the participants individually in resolution of problem situations, sought to relate the considerations of the article with his own practice in everyday school life. Our intention is that the recognized teachers that many of the cases considered difficult in relation to their students and families, can be solved through practical beyond the affectivity as a key element, enabling better recognition and resolution of conflicts and problems.

In the final stage met the whole group again to collectively work the conclusions produced individually. Each participant read to the group received problem situation and told how he thought of resolve it or solve it.

Noteworthy is a summary of contributions to the teaching group produced from the dynamic (Mendes, Dohms, Lettnin, Mosquera, \& Stobäus, 2012).

When students disrupt the class, with inappropriate jokes and lines that hinder the regular progress of the classes, you can try to solve this by using affectivity? An individual and/or small group approach to research, understand and interact better, in a different way, to establish a link and find positive aspects that could be highlighted in the day-to-day classroom. Generally, inadequate attitudes and bad behavior can mask learning difficulties, the experience of teachers. They believe that, especially those students with difficulties, require more teacher support to help them open up to better interact and learn in class.

In situations where, occurs little participation or apparent apathy of students in classes, there is usually no realization of the proposed activities. Teachers exposed positive suggestions for such cases, for example, an approach with students, asking about their tastes, preferences and interests, to understand them better. Call the student to talk individually, if applicable, the part of the class, to not to cause embarrassment, know if you are experiencing some kind of difficulty or problem, try to know your routine out of school. Also look for reason to praise him in front of colleagues, seeking value it positively.

There are moments of conflict between some teachers and some classes in these cases there are other educa- 
tional intervention need to mediate the crisis. First, the teachers indicated the attempt to find out more details about the relationship between the class and the teacher, trying to understand both sides, questioning them about their behavior with him (provocateurs, messy, quiet...). In this sense, seeking to demonstrate that relationships are mutual, there is always an exchange. During the conversation they suggest that people are different and must be respected at all despite differences. Also would talk with the colleague in question, to arrange a meeting between the class and he to establish combinations. If not resolved the situation would the administrative sectors of the school.

The school needs scientificize families attitudes of their children periodically, even when this behavior violates the school's rules of coexistence. Develop a work with families is also part of the school's tasks and manage the "spirits" when it comes to "soft" as well. The teachers suggested that to answer an "exalted" mother is necessary to be quiet, so if dialogue that aggression does not solve the problem, could even worsen the situation. Try to open a respectful conversation and mediated between mother and daughter to clarify the reasons for ill-timed attitudes of student.

Also among the group of teachers and school managers can be situations of lack of communication and empathy between them in relation to an administrative issue of school (meeting on a Saturday, for example). The teachers noted that discussions and strong reactions bring suffering and hinder the resolution of the problem. If teachers believe that a meeting is unnecessary, they should expose managers to their human side, personal, emotional and physical that need to be preserved, even for them to be better professionals. Teachers and managers should ally themselves because they are not on opposite sides, both, each group in a function, working for the better development and student learning.

The group recognized that all cases come out of their school routine, and that certainly have gone through all this. Stressed also that there are several ways to cope and face the events and may have different results, depending on how you refer, and that the bias of affection could be more encouraged in practice in the school context (Mendes, Dohms, Lettnin, Mosquera, \& Stobäus, 2012).

The participants received a form with a few questions so that they could evaluate the workshop and indicate the meaning attributed the activities. They judged that the contents and subjects dealt with were of great interest. Strategies and material support were appreciated as very useful. The teachers felt that the workshop contributed positively to their teaching practice, both to bring new knowledge about affectivity, emotions and feelings, and to review their practices and methodologies. They suggested that the workshop should also be held with the other groups in the school because they think important that this issue be discussed, studied and used in a more concrete way and applied by all the school.

It was assessed as very positive the practice experienced with this workshop. The teachers actively participated in this experience, enriching this moment with their contributions, questions and reflections. It was agreed with the group that would be important to disseminate these studies in training in school service more broadly.

It is understood that the understanding of affectivity can lead to a more positive education by mobilizing teachers and students to experience success and well-being. It is also understood that a teacher training (initial and ongoing) that contemplate the affectivity of issues would benefit the very attitude of teachers towards the students, families and the group of colleagues, as they could also serve as a reference for development their plans and methodologies.

\section{Professional Intervention in a School}

In research conducted by Dohms (2016), in his Doctoral Thesis, which sought to investigate the welfare levels of teachers, students, managers and employees and their perceptions for which were part of the education institution, intended to create spaces and actions concerned with human relationships, then promoting interventions in welfare. Such interventions proposed by the researcher, aimed more productive results, significant and shared success, in order to contribute to the aspects related to interpersonal relationships and healthier institutional environment.

This study included the holding of three interventions, dealing with topics related to Corporate Welfare, and these moments were available, and previously scheduled according to the availability of the schedule of the participating institution of the study, with the participation of faculty, staff and managers of this.

The interventions were proposed according to the research objectives and take into account the participating subjects, the theoretical frameworks and research data addressing the proposed theme. Therefore, these moments 
were designed so that addressed the topic of welfare adapting and improving the ideas to the school level.

For Mosquera (1978), some practical possibilities can assist people in obtaining and maintaining your well-being as the suggestions made by Biehler: develop self-awareness; seek new opportunities for continuing education; evaluate the dissatisfactions; reevaluate the workload; devote time to rest and leisure; chat with friends and family; stimulate discussion in groups with other teachers; seek an enjoyable physical activity; avoid discharging frustrations in students; seek professional help when all aid cited are not sufficient.

Interventions by Dohms (2014) aimed to promote awareness and debate on welfare looking for addressing issues. They would aid participants in your life, not only in the professional aspect, but all those who constitute the human being; clarifying the concepts worked on these issues, realizing and understanding their problematizations; providing moments of reflection, connecting theory and practice, and where possible and/or necessary to make room for discussions that were to contribute to the institution and its agents.

As previously mentioned, these interventions took place in three stages, the first by sending (via email) of two articles to read, related to the central theme- "Welfare and teaching health" (Esteve, 2005) and "Training (Bildung): between the sacred and the profane” (Sattler, 2011). The second intervention occurred in September with a group of faculty, staff and managers, lasting one hour, dealing with broadly Welfare thematic proposing reflections of this relating to the malaise, well-being teaching, meaning and significance of the work, constructs welfare, human beings and their relationships, welfare Institutional, actions and possible strategies for promoting health and well-being.

In this second intervention was observed that the participants were attentive and thoughtful to treated subjects, with few comments from participants during the presentation of themes. Highlighting only speaks of one of the participants stressed the importance of Positive Psychology, perhaps because it his training in psychology, for a "look" more positive and optimistic human being for your life and how these aspects could contribute to make it more healthy and happy.

According to Snyder \& Lopez (2009: p. 19), "both as science and practice of Positive Psychology point to the identification and understanding of the qualities and virtues of the human being, helping to people to have happier and more productive lives".

In this perspective the subjects were treated and at the end there were some reports of the participants, who showed some concern at that time, to realize and give up because of the fast pace that their lives have taken. Most often if ever, the difficulty get to stop and make such reflections, think about their lives, their work, their needs and desires. After this intervention some people reported the researcher that if it were not for that moment for the reflections proposals, surely they would not have been able to think and rethink about their lives, considering the constitutive dimensions of being and the people around you.

For Timm (Santos \& Carreño, 2010), teaching is a helping profession to another, which has the otherness its reason for being. Remember to take care of other does not imply neglecting to Him, because the education of the other always goes through Si education, then the other care will also require a care of himself.

And the third intervention with the participation of some teachers and staff, with a duration of two hours, addressing the issue of welfare, taking into account a deepening of the concept of well-being; the human being in its wholeness, its constituent dimensions and investments that each makes to each of them; Spirituality: meaning and significance of life; Affectivity, emotions and feelings; Positive Psychology; Self-image, Self-Est-eem and Self-realization; and Health Education.

In the latter proposed time, participants interacted more effectively, showing interest in the topics covered, as well as bringing questions and sharing their experiences. It stands out the speech of a participant during the discussions realized the importance of respecting and been elected to contemplate a beautiful sunny day, taking the opportunity to ride a bike or even take a mate instead of organizing materials to be used in the future in their classes, i.e, time management and organization allied to health and well-being. "Give some time to yourself," once participants realize that much of their time is allocated and dedicated only to work, even when they are already in their homes with their families.

Dohms (2011) showed that teachers who participated in his research, dedicated on average 6.22 hours weekly to tasks performed at home (correcting homework, preparing lessons, preparing tests/tests, meeting planning, preparation posters and research materials, etc.), when they should worry about their family life.

These interventions, psycho-pedagogical, were mediated by the researcher, seeking to sensitize participants to the proposed topics, using different resources: texts, videos, music, problem situations and group dynamics. Interventions and notes made concerning these have been used in order to contribute to the institution and com- 
plement the research data.

Rogers (1997) states that the maximum an individual can do for another is to create certain conditions in order to make possible the learning because the person can not be required.

Thinking health, continuing education combined with self-training, reflective training and working together, Dohms (2014) proposed the interventions on welfare in order that all those who constitute the educational institution, though he had sight as the protagonist of this institution.

\section{Conclusion}

We believe that the current challenge of many teachers is to create an environment that provides and promotes well-being in the face of unfavorable situations in which education is located. Worrying to promote the wellbeing of the subject and of others involved for health holistically and hence quality of life, it seems the key to a fulfilling and dignified life, especially for teachers.

The categories in the survey to promote teacher welfare point two paths, an individual nature, where the search depends exclusively on the subject, and other social, the aid and the other's gaze in relation to the subject become fundamental. A closer look at the elements of Positive Psychology, such as health, quality of life, well-being, resilience, coping and affectivity, may favor the vital development of teachers and achieve the goals of personal and professional life successfully.

The goals established in each individual life cycle and each career step should be considered as the source of energy that keeps the constant search for human development and teaching, respectively.

Understand human development as an ongoing process of personal and professional construction is an important strategy for healthy living and quality, including teachers.

This article made a reflection about some themes that run through teacher training, including interventions performed reports, in order to understand and reflect aspects for the construction of the human being as a teacher. In this sense, we conclude that the construction of the subject is through the choices, the paths taken, the adopted strategies, involvement, experience, making every single person and the author of his own existence. Therefore, healthy living and physical well-being, affective-emotional and cognitive development is a right and a duty of all of us teachers!

\section{References}

Arantes, V. A. (2003). Afetividade na escola: Alternativas teóricas e práticas. [Affectivity in the School: Theoretical and Practical Alternatives]. São Paulo: Summus.

Bardin, L. (2006). Análise de Conteúdo (3rd ed.). [Content Analysis]. Lisboa: Edições, 70.

Casassus, J. (2009). Fundamentos da educação emocional. [Fundaments of Emotional Education]. Brasília: UNESCO, Liber Livro Editora.

Da Lettnin, C. C., Zacharias, J., Mendes, A. R., Dohms, K. P., Mosquera, J. J. M., \& Stobäus, C. D. (2011). Bem-estar docente e Neuropsicopedagogia: Contribuições para a formação pessoal e profissional [Teachers Well-Being and Neuropsicopedagogy: Contributions for Personal and Professional Education]. In III Seminário Internacional Pessoa Adulta, Saúde e Educação, Porto Alegre. Espaços Psicopedagógicos em Diferentes Cenários. Anais... (pp. 1-16).

Diener, E. (2000). Subjective Well-Being: The Science of Happiness and Proposal for a National Index. American Psychologist, 55, 34-43. http://dx.doi.org/10.1037/0003-066X.55.1.34

Dohms, K, P. (2016). Bem-Estar Institucional em uma escola da rede marista. [Institutional Welfare on a Marist School Network]. Porto Alegre: Tese (Doutorado em Educação)-Escola de Humanidades da PUCRS.

Dohms, K, P., Lettnin, C. da C., Mendes, A. R., Mosquera, J. J. M., \& Stobäus, C. D. (2014). Affectivity of University Teachers: Personal, Social and Institutional Aspects. Psychology, 5, 1783-1793. http://dx.doi.org/10.4236/psych.2014.515185

Dohms, K, P., Stobäus, C. D., \& Mosquera, J. J. M. (2012). Níveis de mal/bem-estar, autoimagem e autoestima e autorrealização de docentes em uma escola tradicional de Porto Alegre. [Levels of Malaise/Well-Being, Self-Image and SelfEsteem and Self-Realization of Teachers in a Traditional School of Porto Alegre]. Revista Série-Estudos, 34. http://www.serie-estudos

Dohms, K. P. (2011). Mal/bem-estar docente, auto-imagem e auto-estima e auto-realização em uma escola tradicional de Porto Alegre. [Teachers Malaise/Well-Being, Self-Image and Self-Esteem and Self-Realization in a Traditional School of Porto Alegre]. Dissertação (Mestrado em Educação), Porto Alegre: Faculdade de Educação da PUCRS.

Esteve, J. M. (2005). Bem-estar e saúde docente. [Welfare and Teachers Health]. Revista PRELAC. Educação para todos. 
Publicado pelo Escritório Regional de Educação da UNESCO para a América Latina e o Caribe. OREALC/UNESCO Santiago. Impresso no Chile por AMF Imprenta. Santiago, Chile: ano I, 116-133.

Grotberg, E. H. (2003). Nuevas tendencias en resiliencia. [New Tendecies in Resilience]. In A. Melillo, \& E. N. S. Ojeda (Eds.), Resiliencia: Descubriendo las propias fortalezas. Buenos Aires: Paidós.

Huberman, M. (1995). O ciclo de vida profissional dos professores. [Professional Life Cycle of Teachers] In A. Nóvoa (Ed.), Vidas de Professores (2nd ed.). Lisboa: Porto Editora.

Jesus, S. N. de (2007). Professor sem stress: Realização profissional e bem-estar docente. [Teacher Stress: Professional Achievement and Teacher Welfare]. Porto Alegre: Mediação.

Jesus, S. N. de, \& Rezende, M. (2009). Saúde e Bem-Estar. [Health and Well-Being]. In J. Cruz, S. N. de Jesus, \& C. Nunes (Eds.), Bem-estar e qualidade de vida: Contributos da Psicologia da Saúde. Porto: Textiverso.

Jesus, S. N. de, Sampaio, A. A., Stobäus, C. D., \& Mosquera, J. J. M. (2008). Promoção do bem-estar docente através de programa de formação continuada. [Promoting Teaching Wellness through Continuing Education Program]. Polimorfia (Mato Grosso), 5, 83-88.

Jesus, S. N. et al. (2011). Avaliação da motivação e do bem/mal-estar dos professores: Estudo comparativo entre Brasil e Portugal. [Motivation and Evaluation of Welfare/Malaise of Teachers: A Comparative Study between Brazil and Portugal.] Amazônica-Revista de Psicopedagogia, Psicologia Escolar e Educação, 7, 7-18.

Marchesi, Á. (2008). O bem-estar dos professores [The Teachers’ Welfare]. Porto Alegre: Artmed.

Maslow, A. (1991). Motivación y Personalidad [Motivation and Personality]. Madrid: Ediciones Díaz de Santos.

Mendes, A. R. (2011). Saúde docente: Uma realidade detectada-em direção ao bem-estar e a realização profissional [Teachers Health: A Detected Reality—Toward the Well-Being and Professional Fulfillment]. Dissertação (Mestrado em Educação)—Faculdade de Educação, Porto Alegre: Pontifícia Universidade Católica do Rio Grande do Sul.

Mendes, A. R., Dohms, K. P., da Lettnin, C. C., Mosquera, J. J. M., \& Stobäus, C. D. (2012). Reflexões teórico-práticas: Elementos para a formação pessoal e profissional de professores [Theoretical and Practical Reflections: Elements for Personal and Professional Teacher Education]. In Y. P. Morel, M. J. M. de Lima, \& Z. D. Martins (Org.), Armazém de Ideias IV: Momentos... Articulando a Ação Pedagógica no Trabalho Coletivo (pp. 9-21). Porto Alegre: ASSERS.

Mendes, A. R., Dohms, K. P., Zacharias, J., Da Lettnin, C. C., Mosquera, J. J. M., \& Stobäus, C. D. (2011). Bem-estar docente: Indicadores e subsídios [Teachers Well-Being: Indicators and Subsidies]. In II Congresso Luso-Brasileiro de Psicologia da Saúde e I Congresso Ibero-Americano de Psicologia da Saúde, São Bernardo do Campo. Transformações Socioculturais e Promoção de Saúde. Anais... (pp. 1-34).

Mosquera, J. J. M. (1978). O professor como pessoa [The Teacher as a Person]. Porto Alegre: Sulina.

Mosquera, J. J. M., \& Stobäus, C. D. (2006). Afetividade: A manifestação de sentimentos na educação [Affectivity: The Expression of Feelings in Education]. Educação, Porto Alegre, 29, 123-133.

Mosquera, J. J. M., \& Stobäus, C. D. (2008). O professor, personalidade saudável e relações interpessoais: por uma educação para a afetividade [The Teacher, Healthy Personality and Interpersonal Relations: For an Education for Affectivity]. In D. Enricone (Org.), Ser Professor. Porto Alegre: EdiPUCRS.

Mosquera, J. J. M., Stobäus, C. D., Jesus, S. N. de, \& Hermínio, C. I. (2006). Auto-imagem, auto-estima e auto-realização na universidade [Self-Image, Self-Esteem and Self-Realization in the University]. UNIrevista, 1, 1-13.

Pais-Ribeiro, J. L. (2009). A importância da qualidade de vida para a psicologia da saúde [The Importance of Quality of Life for Health Psychology]. In: J. Cruz, S. N. de Jesus, \& C. Nunes (Coord.), Bem-Estar e Qualidade de Vida: Contributos da Psicologia da Saúde. Portugal: Textiverso.

Pais-Ribeiro, J. L., \& Santos, C. (2001). Estudo conservador de adaptação do Ways of Coping Questionnaire a uma amostra e contexto portugueses [Conservative Study of Adaptation of the Ways of Coping Questionnaire to a Sample and Portuguese Context]. Análise Psicológica, Lisboa, 19, 491-502. http://www.scielo.oces.mctes.pt/pdf/aps/v19n4/v19n4a01.pdf

Rogers, C. R. (1997). Tornar-se pessoa [Becomming a Person]. São Paulo: Martins Fontes.

Santos, B. S. S., \& Carreño, A. B. (2010). A motivação em diferentes cenários [The Motivation in Different Scenarios]. Porto Alegre: EDIPUCRS.

Sattler, M. (2011). Formação (Bildung): Entre o sagrado e o profano [Education (Bildung): Between the Sacred and the Profane]. Educação, Porto Alegre, 34, 49-55.

Seligman, M., \& Csikszentmihalyi, M. (2000). Positive Psychology. American Psychologist, 55, 5-14. http://dx.doi.org/10.1037/0003-066X.55.1.5

Snyder, C. R., \& Lopez, S. J. (2009). Psicologia Positiva: Uma abordagem científica e prática das qualidades humanas [Positive Psychology: A Scientific and Practical Approach of Human Qualities]. Porto Alegre: Artme.

Sousa, C. (2006). Educação para a resiliência [Education and Resilience]. Tavira: Município de Tavira. 
Tavares, J. (2001). A resiliência na sociedade emergente [Resilience in the Emerging Society]. In J. Tavares (Org.), Resiliência e Educação. São Paulo: Cortez.

Timm, E. Z., Mosquera, J. J. M., \& Stobäus, C. D. (2008). Resiliência: Necessidade e possibilidade de problematização em contextos de docência [Resilience: The Need and Possibility of Questioning in Teaching Contexts]. Educação, Porto Alegre, 31, 39-45.

Zacharias, J., Mendes, A. R., Lettnin, C. da C., Dohms, K. P., Mosquera, J. J. M., \& Stobäus, C. D. (2011). Saúde e Educação: Do mal-estar ao bem-estar docente [Health and Education: The Malaise to Teaching Wellness]. Revista Educação por Escrito-PUCRS, 2, 17-30.

\section{Submit or recommend next manuscript to SCIRP and we will provide best service for you:}

Accepting pre-submission inquiries through Email, Facebook, Linkedin, Twitter, etc A wide selection of journals (inclusive of 9 subjects, more than 200 journals)

Providing a 24-hour high-quality service

User-friendly online submission system

Fair and swift peer-review system

Efficient typesetting and proofreading procedure

Display of the result of downloads and visits, as well as the number of cited articles

Maximum dissemination of your research work

Submit your manuscript at: http://papersubmission.scirp.org/ 